\title{
Panic disorder and psychoactive substance use in primary care
}

\author{
Transtorno do pânico e uso de substâncias psicoativas \\ na atenção primária
}

\author{
Andressa Jacondino Pires, ${ }^{1,2}$ Camila Corrêa Casanova, ${ }^{3,4}$ Luciana de Avila Quevedo, ${ }^{1,5}$ Karen Jansen, ${ }^{1,5}$ \\ Ricardo Azevedo da Silva ${ }^{1,6}$
}

\begin{abstract}
Objective: To identify the association between panic disorder and licit and illicit substance use in the population provided with primary care in the southern Brazil.

Methods: This is a cross-sectional study with patients from three primary care centers. We used the Alcohol, Smoking and Substance Involvement Screening Test (ASSIST) to evaluate substance use and the Mini International Neuropsychiatric Interview (MINI) to diagnose panic disorder.

Results: A total of 1,081 subjects were evaluated. The prevalence of panic disorder was $5.6 \%$. Panic disorder was associated with using marijuana $(p=0.001)$, tobacco $(p=0.001)$, cocaine $(p<0.001)$, and other illicit substances $(p<0.001)$.

Conclusion: A significant association is noticed between panic disorder and licit and illicit substance use, thus, it is interesting to rethink the approach to treatment/intervention in patients with dual diagnosis.
\end{abstract}

Keywords: Panic disorder, substance-related disorders, anxiety disorders.

\section{Resumo}

Objetivo: Identificar a associação entre transtorno do pânico e uso de substâncias lícitas e ilícitas na população atendida na atenção primária no sul do Brasil.

Métodos: Este é um estudo transversal com pacientes de três centros de cuidados primários. Foi usado o Teste de Triagem do Envolvimento com Álcool, Tabaco e Outras Substâncias (ASSIST) para avaliar o uso de substâncias e a Mini International Neuropsychiatric Interview (MINI) para diagnosticar o transtorno do pânico.

Resultados: Um total de 1.081 pacientes foram avaliados. A prevalência de transtorno do pânico foi de 5,6\%. O transtorno do pânico foi associado com o uso de maconha $(p=0,001)$, tabaco ( $p=0,001)$, cocaína $(p<0,001)$ e outras substâncias ilícitas ( $p$ $<0,001)$.

Conclusão: Foi observada uma associação significativa entre transtorno do pânico e uso de substâncias lícitas e ilícitas. Por este motivo, é interessante repensar a abordagem de tratamento/intervenção em pacientes com duplo diagnóstico.

Descritores: Transtorno do pânico, distúrbios relacionados a substâncias, transtornos de ansiedade.

\footnotetext{
${ }^{1}$ Graduate Program in Health and Behavior, Universidade Católica de Pelotas (UCPel), Pelotas, RS, Brazil. 2 Psychologist. MSc candidate, Graduate Program in Health and Behavior, UCPel, Pelotas, RS, Brazil. ${ }^{3}$ School of Psychology, UCPel, Pelotas, RS, Brazil. ${ }^{4}$ Psychologist, UCPel, Pelotas, RS, Brazil. ${ }^{5}$ Psychologist. PhD candidate, Graduate Program in Health and Behavior, UCPel, Pelotas, RS, Brazil. ${ }^{6}$ PhD in Clinical Psychology, Graduate Program in Health and Behavior, UCPel, Pelotas, RS, Brazil.

The present study was carried out at the Graduate Program in Health and Behavior, Universidade Católica de Pelotas (UCPel), Pelotas, RS, Brazil. Financial support: Centro Nacional de Desenvolvimento Científico e Tecnológico (CNPq).

Submitted Sep 11 2013, accepted for publication Apr 01 2014. No conflicts of interest declared concerning the publication of this article.

Suggested citation: Pires AJ, Casanova CC, Quevedo LA, Jansen K, da Silva RA. Panic disorder and psychoactive substance use in primary care. Trends Psychiatry Psychother. 2014;36(2):113-118. http://dx.doi.org/10.1590/2237-6089-2013-0042
} 


\section{Introduction}

Anxiety disorder and substance use constitute a target subject for many researchers, but just a few studies explore the relation between a specific type of this disorder and licit and illicit substance use.

Panic attacks are characterized by cognitive and, especially, physical symptoms, such as tachycardia, shortness of breath, sweating, trembling, which arise abruptly and reach their peak within 10 minutes. When these attacks occur repeatedly and the individual becomes afraid of the emergence of new attacks, this disorder is present. The prevalence of panic disorder ranges from 1.7 to $3.7 \%$ among the population as a whole. ${ }^{1,2}$ Individuals with this disorder are concerned about the consequences of their attacks, such as going crazy, losing control, or having a heart attack ${ }^{3}$ and they seek health care more often, due to the organic nature of symptoms. Correct identification of panic disorder is extremely important for an effective intervention in the high rates of comorbidity that accompany it, especially with regard to substance use.

A diagnosed panic disorder may be with or without agoraphobia. The latter is defined as anxiety about being in places or situations from which escape might be difficult or in which help may not be available in case of having an unexpected panic attack. ${ }^{3}$ Panic disorder patients typically have panic attacks before agoraphobia. ${ }^{4}$

There is a positive correlation between drug use, such as tobacco, and psychological disorders. ${ }^{3}$ Smoking prevalence is higher among those who have some type of disorder and there is also strong evidence on the relation between using tobacco and the first panic attack. ${ }^{5}$ There are reports of nicotine use as a practice that patients regard as useful to control panic attacks. This description is probably related to the perception of sedative effects in nicotine, by stimulating the adrenergic system. Smokers associate the act of smoking with relief from anxiety, thus they tend to use tobacco in stressful situations. Smoking can trigger a panic attack, and the possibility that smoking is triggered by attacks is not ruled out. ${ }^{6}$

Alcohol-dependent individuals have higher prevalence of anxiety disorders when compared to the population as a whole. According to a study conducted in Brazil, the chronological relation between panic disorder and alcohol abuse is controversial, i.e. the disorder may be the precedent of alcohol use or derive from it. ${ }^{7}$

Illicit substance use is related to many types of anxiety disorders. According to a study conducted in 2009, ${ }^{8}$ individuals with panic disorder tend to have substance use disorders in the future. Another study ${ }^{9}$ shows that lifetime marijuana use is strongly associated with panic attacks and panic disorder history. Non-medical prescription opioids are also related to panic disorder, but it is not possible to claim what takes place first. ${ }^{10}$

Evidence show that patients with dual diagnosis, panic disorder and substance use, require a pharmacotherapy different from that of patients with a single diagnosis. ${ }^{11}$ These patients are prone to greater difficulty in achieving and maintaining abstinence and adherence to treatment is less frequent. They need intensive care, including careful evaluation on using the appropriate control for comorbid pharmacotherapy, not forgetting the possibility of an interaction between nicotine and countless other drugs.

This study aims to identify and report the prevalence of panic disorder and licit and illicit substance use among the population provided with primary care at three centers connected to Universidade Católica de Pelotas (UCPel), Brazil. This is a subject still poorly explored that deserves greater attention.

\section{Method}

This is a cross-sectional study carried out with patients provided with primary care at three centers connected to UCPel. It has been approved by the Research Ethics Committee of this institution. Eligible individuals were patients older than 14 years who sought medical care every two days within the period from July to December 2009 and lived within the coverage area of the centers under investigation. We recorded 1,516 cases requiring health care and 1,266 patients could be interviewed. Patients who did not live within the coverage area and those who had some difficulty to understand the instruments were excluded.

At the identification stage, carried out from June 29 to August 20, 2009, the primary care centers were visited and professionals were informed about the survey and invited to participate in it. At the next stage, after training a team of interviewers, home visits were conducted from July 6 to December 2, 2009, in order to collect data from patients identified at the previous stage. At the time of each visit, a questionnaire addressing demographic information, morbidity, and use of health care resources was applied, after participant's signing of the free and informed consent term. The interviews were conducted at patients' home by psychologists and Psychology students, who were trained and supervised to perform such activity by psychologists who are experienced on using the instruments applied. The average duration of interviews was 90 minutes.

These primary care centers are sought by the economically disadvantaged population. The highest demand comes from women and patients with chronic and acute illnesses; $14 \%$ of the sample reported to have some major disease. 
We used the Alcohol, Smoking and Substance Involvement Screening Test (ASSIST) ${ }^{12}$ to evaluate substance use. This is a self-applied scale aiming to check current and lifetime legal substance use - alcohol and tobacco - and illegal substance use - marijuana, cocaine, crack, stimulants, inhalants, hypnotics, sedatives, hallucinogens, and opioids. In this survey, we adopted questions related to lifetime use, included in the first module of the instrument.
Table 1 - Prevalence of panic disorder among patients provided with primary care at three centers in Pelotas, Rio Grande do Sul, Brazil

\begin{tabular}{ll}
\hline Type of panic disorder & $\mathbf{n}(\%)$ \\
\hline Current panic disorder & $60(5.6)$ \\
Lifelong panic disorder & $88(8.1)$ \\
Panic disorder with agoraphobia & $45(4.2)$ \\
Panic disorder without agoraphobia & $15(1.4)$ \\
\hline
\end{tabular}

Table 2 - Characteristics of individuals with current panic disorder in relation to sociodemographic data and licit and illicit substance use among patients provided with primary care at three centers in Pelotas, Rio Grande do Sul, Brazil

\begin{tabular}{|c|c|c|c|c|}
\hline Variables & $\begin{array}{c}\text { Sample distribution } \\
\text { n (\%) }\end{array}$ & $\begin{array}{l}\text { Current panic } \\
\text { disorder } \\
\text { n (\%) }\end{array}$ & $\begin{array}{c}\text { Prevalence ratio/difference } \\
\text { between means } \\
(95 \% \mathrm{CI})\end{array}$ & p* \\
\hline Gender & & & & 0.427 \\
\hline Female & $771(71.3)$ & $46(6.0)$ & $1.32(0.73-2.37)$ & \\
\hline Male & $310(28.7)$ & $14(4.5)$ & 1.00 & \\
\hline Age & & & & 0.002 \\
\hline 14-19 (adolescent) & $82(7.6)$ & $3(3.7)$ & $3.84(0.79-18.70)$ & \\
\hline 20-59 (adult) & $684(63.3)$ & $54(7.9)$ & $8.29(2.61-26.32)$ & \\
\hline 60 or more (elderly) & $315(29.1)$ & $3(1.0)$ & 1.00 & \\
\hline Socioeconomic status & & & & 0.235 \\
\hline $\mathrm{A}+\mathrm{B}$ (upper class) & $111(10.4)$ & $5(4.5)$ & 1.00 & \\
\hline C (middle class) & $646(60.7)$ & $32(5.0)$ & $1.10(0.44-2.76)$ & \\
\hline $\mathrm{D}+\mathrm{E}$ (lower class) & $308(28.9)$ & $21(6.8)$ & $1.51(0.58-3.92)$ & \\
\hline Educational level & & & & 0.708 \\
\hline $0-3$ years of schooling & $308(28.8)$ & $15(4.9)$ & $1.14(0.56-2.33)$ & \\
\hline 4-7 years of schooling & $432(40.4)$ & $29(6.7)$ & $1.58(0.85-2.94)$ & \\
\hline $8-16$ years of schooling & $329(30.8)$ & $14(4.3)$ & 1.00 & \\
\hline Current job & & & & 1.000 \\
\hline No & $730(67.5)$ & $41(5.6)$ & $1.04(0.61-1.76)$ & \\
\hline Yes & $351(32.5)$ & $19(5.4)$ & 1.00 & \\
\hline Alcohol use $^{+}$ & & & & 0.518 \\
\hline No & $477(44.6)$ & $23(4.8)$ & 1.00 & \\
\hline Yes & $592(55.4)$ & $35(5.9)$ & $1.22(0.73-2.05)$ & \\
\hline Tobacco use ${ }^{+}$ & & & & 0.001 \\
\hline No & $560(52.4)$ & $18(3.2)$ & 1.00 & \\
\hline Yes & $509(47.6)$ & $40(7.9)$ & $2.44(1.42-4.21)$ & \\
\hline Marijuana use & & & & 0.001 \\
\hline No & 1,205 (95.9) & $50(4.9)$ & 1.00 & \\
\hline Yes & $44(4.1)$ & $8(18.2)$ & $3.73(1.88-7.38)$ & \\
\hline Cocaine use ${ }^{+}$ & & & & 0.000 \\
\hline No & $1,050(98.2)$ & $53(5.0)$ & 1.00 & \\
\hline Yes & $19(1.8)$ & $5(26.3)$ & $5.21(2.35-11.57)$ & \\
\hline Use of other illicit substances ${ }^{\dagger \neq}$ & & & & 0.000 \\
\hline No & $1,001(93.6)$ & $47(4.7)$ & 1.00 & \\
\hline Yes & $68(6.4)$ & $11(16.2)$ & $3.44(1.87-6.33)$ & \\
\hline Total & $1,081(100)$ & $60(5.6)$ & - & - \\
\hline
\end{tabular}

$95 \% \mathrm{CI}=95 \%$ confidence interval.

$*$ Chi-square; ${ }^{+}$lifetime use; ${ }^{\ddagger}$ stimulants, inhalants, hypnotics, sedatives, hallucinogens, or opioids. 
Table 3 - Association between panic disorder and substance use adjusted by Poisson regression for age among patients provided with primary care at three centers in Pelotas, Rio Grande do Sul, Brazil

\begin{tabular}{lcc}
\hline Variables & $\begin{array}{c}\text { Prevalence ratio } \\
(\mathbf{9 5 \%} \mathbf{C I})\end{array}$ & $\mathbf{p}$ \\
\hline Tobacco use* & 1.00 & \\
$\quad$ No & $2.64(1.53-4.55)$ & 0.000 \\
$\quad$ Yes & & \\
Marijuana use* & 1.00 & \\
$\quad$ No & $3.31(1.64-6.62)$ & 0.001 \\
$\quad$ Yes & & \\
Cocaine use* & 1.00 & \\
$\quad$ No & $4.37(1.89-10.09)$ & 0.001 \\
$\quad$ Yes & & \\
Use of other illicit substances*+ & 1.00 & \\
No & $3.68(2.00-6.76)$ & 0.000 \\
Yes & & \\
\hline
\end{tabular}

$95 \% \mathrm{CI}=95 \%$ confidence interval.

* Lifetime use; ${ }^{+}$stimulants, inhalants, hypnotics, sedatives, hallucinogens, or opioids.

For diagnosing panic disorder, we used the Mini International Neuropsychiatric Interview (MINI), in its brief version, ${ }^{13}$ which is in line with criteria from the Diagnostic and Statistical Manual of Mental Disorders, 4th edition (DSM-IV), and the International Statistical Classification of Diseases and Related Health Problems (ICD-10). In addition to the diagnostic interview, patients answered to a questionnaire about socioeconomic status. We adopted the classification proposed by the Brazilian Association of Research Companies (ABEP) to evaluate families' socioeconomic status; this is based on the accumulation of material wealth and household head's educational level, classifying the subjects into five levels (A, B, C, D, and E). ${ }^{14}$ Questionnaires were applied by psychologists/psychiatrists trained to conduct interviews at patients' home.

Chi-square statistical test and $t$ test were used to compare proportions. The variable "age" was considered a confounder for presenting $p<0.20$, thus substance use was adjusted through Poisson regression for age. Statistical analysis was performed using the software SPSS 10.0 for Windows.

Patients with mental disorders who sought primary care at centers that cannot offer a specialized treatment were referred to the Psychiatric Outpatient Clinic of UCPel.

\section{Results}

The sample consisted of 1,266 individuals. Out of these, 39 refused participation, 2 patients died between the identification and interview dates, and 144 were not found at the addresses informed. Then, 1,081 subjects were interviewed. The prevalence of current panic disorder was $5.6 \%(n=60)$ among the total sample and the prevalence of lifetime panic disorder was $8.1 \%$ ( $n=$ 88 ) among the total sample. Concerning substance use, amog 60 patients with panic disorder, 40 used tobacco, 8 used marijuana, 5 used cocaine, and 11 used other illicit substances (stimulants, inhalants, hypnotics, sedatives, hallucinogens, or opioids).

Table 1 shows sample's distribution. Panic disorder was associated with age $(p=0.002)$, tobacco use ( $p$ $=0.001)$, marijuana use $(p=0.001)$, cocaine and/ or crack use $(p=0.000)$ and use of other illicit substances - stimulants, inhalants, hypnotics, sedatives, hallucinogens, and opioids ( $p=0.000)$.

After being adjusted for age, tobacco use, marijuana use, cocaine and/or crack use, and use of other illicit substances remained associated with panic disorder (Table 2). Subjects who used, at least once, tobacco, marijuana, cocaine, and/or crack and other illicit substances showed at least two times higher probability to have current panic disorder (Table 3).

\section{Discussion}

This study found the prevalence of $5.6 \%(n=60)$ of individuals with current panic disorder, while a study about the prevalence of psychopathology among patients from a primary care center in Spain found that 3\% of them had panic disorder. ${ }^{15}$ In an epidemiological study about panic disorder carried out in 10 countries, with over 40,000 individuals, the prevalence of panic disorder ranged from 1.4 to $2.9 \%$. Thus, we may claim that the prevalence of panic disorder observed in this study was twice higher than that found by previous studies. This finding may be due to the fact that this study relied on a sample of individuals who sought primary care centers, thus, they are more likely to have some illness than individuals included in samples for population studies.

Studies show that genetic factors are related to the emergence of panic disorder, and there is no difference in genes between men and women. Among the anxiety disorders, panic disorder shows much evidence of heredity and genetic influence. ${ }^{16-18}$

This study found a strong relation between panic disorder and use of tobacco, marijuana, cocaine and/or crack, and other illicit substances. Psychiatric disorders occur more frequently among individuals who use drugs than among those who do not use them. ${ }^{19}$

Our findings are consistent with those from a study conducted in 2013, which claims that diagnosed substance abuse may occur before or after an anxiety disorder and a history of substance use helps predicting the emergence of a panic disorder. ${ }^{20}$ 
The association between panic disorder and smoking is confirmed by other studies, which point out that smokers tend to have significantly more anxiety disorders than non-smokers. ${ }^{21-24}$ Epidemiological studies show that the prevalence of smoking among patients with panic disorder is higher than that found among the population as a whole. Moreover, in most cases, smoking precedes the onset of disorder, suggesting that tobacco use may be a risk factor for the disorder. ${ }^{22,23}$ However, other studies suggest that panic disorder does not increase the risk of smoking, ${ }^{24,25}$ and it can be a motivating factor for people to stop smoking.

Regarding nicotine withdrawal, individuals with panic disorder have a tendency to show more severe symptoms than those with other disorders. It is due to the fact that lack of nicotine produces symptoms similar to those of panic attacks. Misinterpretation of bodily sensations of danger and threat may increase anxiety symptoms, and this may lead to stricter withdrawal criteria. ${ }^{26}$

A cross-sectional study ${ }^{11}$ points out a relation between cannabis use and panic disorder, corroborating our findings. People used to believe that panic disorder was most strongly correlated to individuals addicted to marijuana; however, it is observed that the disorder has a strong relation to users who are not dependent on the drug. Another study, conducted in 2008, shows that marijuana use may be a risk factor for panic disorder ${ }^{27}$; that study also points out the relation between smoking and panic disorder, claiming that marijuana use tends to occur along with tobacco use.

Cocaine use can trigger various health problems, including panic disorder. ${ }^{28} \mathrm{~A}$ cohort study with community samples showed that there are previous references that cocaine users are three times more likely to have panic disorder and that using this substance can trigger the disorder, however, it is worth emphasizing that this is a cross-sectional study, thus it is not possible to determine causality between panic disorder and substance use. ${ }^{29}$

Regarding other illicit substances, a study conducted in 2009 found a weak but significant association between opioid use and panic disorder, ${ }^{22}$ as it was found by this study; just like the study conducted with two community samples, it found a significant relation between panic disorder and the use of stimulants and hallucinogens. ${ }^{30}$

It has been noticed that panic disorder is related to substance use, ${ }^{15,21,22}$ however, it is not possible to claim that the first triggers drug use, or vice versa. In 2012, a study ${ }^{31}$ pointed out that panic attacks may favor selfmedication, due to the extremely uncomfortable features of panic attacks. Glantz et al. ${ }^{32}$ found that panic disorder occurs prior to using some substance. Regarding alcohol use, it has been claimed to precede panic disorder. ${ }^{33}$ Although this study confirms the hypothesis that there is a significant relation between panic disorder and licit and illicit substance use, there is a methodological constraint, since data were obtained from only three primary care centers in a southern Brazilian town. Another limitation is the fact that panic disorder is often associated with other disorders, such as depression and bipolar disorder, and this may be a confounder, since these disorders were not evaluated in this study. Thus, there is a need for further investigation on this issue.

\section{Conclusion}

This study showed the importance of detecting substance use along with panic disorder so that a treatment can be planned and put into practice for the patient, relieving symptoms and improving quality of life. Patients with dual diagnosis should undergo specific treatments, and this approach may require addressing substance use before treating panic disorder. In this way, if panic disorder is dealt with effectively at a second stage, concrete improvement could be obtained.

\section{References}

1. Viana MC, Andrade LH. Lifetime Prevalence, age and gender distribution and age-of-onset of psychiatric disorders in the São Paulo Metropolitan Area, Brazil: results from the São Paulo Megacity Mental Health Survey. Rev Bras Psiquiatr. 2012;34:249-60.

2. Kessler RC, Chiu WT, Jin R, Ruscio AM, Shear K, Walters EE. The epidemiology of panic attacks, panic disorder, and agoraphobia in the National Comorbidity Survey Replication. Arch Gen Psychiatry. 2006;63:415-24.

3. American Psychiatric Association. Diagnostic and Statistical Manual of Mental Disorders - 4th edition (DSM-IV). Washington: APA; 1995.

4. Aronson TA, Logue CM. On the longitudinal course of panic disorder: development history and predictors of phobic complications. Compr Psychiatry 1987;28:344-55.

5. Lopes FL, Nascimento I, Zin WA, Valença AM, Mezzasalma MA, Figueira I. Smoking and psychiatric disorders: a comorbidity survey. Braz J Med Biol Res. 2002;35:961-7.

6. Malbergier A, Oliveira Jr HP. [Tobacco dependence and psychiatric comorbity]. Rev Psiquiatr Clín. 2005;32:276-82.

7. Terra MB, Figueira I, Athayde LD. Fobia social e transtorno de pânico: relação temporal com dependência de substâncias psicoativas. Rev. psiquiatr. Rio Gd. Sul. 2003;25:436-43.

8. Grant BF, Goldstein RB, Chou SP, Huang B, Stinson FS, Dawson $D A$, et al. Sociodemographic and psychopathologic predictors of first incidence of DSM-IV substance use, mood and anxiety disorders: results from the Wave 2 National Epidemiologic Survey on Alcohol and Related Conditions. Mol Psychiatry. 2009;14:105166. Epub 2008 Apr 22.

9. Zvolensky MJ, Cougle JR, Johnson KA, Bonn-Miller MO, Bernstein A. Marijuana use and panic psychopathology among a representative sample of adults. Exp Clin Psychopharmacol. 2010;18:129-34.

10. Martins SS, Fenton MC, Keyes KM, Blanco C, Zhu H, Storr CL. Mood and anxiety disorders and their association with non-medical prescription opioid use and prescription opioid-use disorder: longitudinal evidence from the National Epidemiologic Study on Alcohol and Related Conditions. Psychol Med. 2012;42:1261-72. Epub 2011 Oct 17.

11. Calheiros PRV, Oliveira MS, Andretta I. Comorbidades psiquiátricas no tabagismo. Aletheia. 2006;23:65-74.

12. WHO ASSIST Working Group. The Alcohol, Smoking and Substance Involvement Screening Test (ASSIST): development, reliability and feasibility. Addiction. 2002;97:1183-94. 
13. Amorim P. Mini International Neuropsychiatric Interview (MINI): validação de entrevista breve para diagnóstico de transtornos mentais. Rev Bras Psiquiatr 2000;22:106-15.

14. Associação Brasileira de Empresas de Pesquisa (ABEP). Dados com base no Levantamento Sócio Econômico (IBOPE); 2003. http://www.abep.org.br. Accessed 2010 Feb.

15. Chocrón Bentata L, Vilalta Franch J, Legazpi Rodríguez I, Auquer $\mathrm{K}$, Franch L. [Prevalence of psychopathology at a primary care center]. Aten Primaria. 1995;16:586-90, 592-3.

16. Hettema JM, Neale MC, Kendler KS. A review and meta-analysis of the genetic epidemiology of anxiety disorders. Am J Psychiatry. 2001;158:1568-78.

17. Koido K, Traks T, Balõtšev R, Eller T, Must A, Koks S, et al. Associations between LSAMP gene polymorphisms and major depressive disorder and panic disorder. Transl Psychiatry. 2012;2:e152.

18. Al-Haddad MK, Sequeira RP, Nayar U. Neurobiological correlates of panic disorder and agoraphobia. J Postgrad Med. 2001;47:55-61.

19. Wang PS, Berglund P, Kessler RC. Recent care of common mental disorders in the United States: prevalence and conformance with evidence-based recommendations. J Gen Intern Med. 2000;15:284-92.

20. Goodwin RD, Stein DJ. Anxiety disorders and drug dependence: evidence on sequence and specificity among adults. Psychiatry Clin Neurosci. 2013;67:167-73.

21. Martins SS, Keyes KM, Storr CL, Zhu H, Chilcoat HD. Pathways between nonmedical opioid use/dependence and psychiatric disorders: results from the National Epidemiologic Survey on Alcohol and Related Conditions. Drug Alcohol Depend. 2009;103:16-24. Epub 2009 May 2.

22. Tanios CY, Abou-Saleh MT, Karam AN, Salamoun MM, Mneimneh ZN, Karam EG. The epidemiology of anxiety disorders in the Arab world: a review. J Anxiety Disord. 2009;23:409-19. Epub 2008 Oct 31.

23. Amering $M$, Bankler $B$, Berger $P$, Griengl $H$, Windhaber J, Katschnig. H. Panic disorder and cigarette smoking behavior. Compr Psychiatry. 1999;40:35-8.

24. Bernstein A, Zvolensky MJ, Schmidt NB, Sachs-Ericcson N. Developmental course(s) of lifetime cigarette use and panic attack comorbidity: an equifinal phenomenon? Behav Modif. 2007;31:117-35.
25. Johnson JG, Cohen P, Pine DS, Klein DF, Kasen S, Brook JS. Association between cigarette smoking and anxiety disorders during adolescence and early adulthood. JAMA. 2000;284:2348-51.

26. Lopes FL, Nascimento I, Zin WA, Valença AM, Mezzasalma MA, Figueira I, et al. Smoking and psychiatric disorders: a comorbidity survey. Braz J Med Biol Res. 2002;35:961-7.

27. Zvolensky MJ, Lewinsohn P, Bernstein A, Schmidt NB, Buckner JD, Seeley J, et al. Prospective associations between cannabis use, abuse, and dependence and panic attacks and disorder. J Psychiatr Res. 2008;42:1017-23. Epub 2008 Feb 20.

28. Karila L, Lowenstein W, Coscas S, Benyamina A, Reynaud M. [Complications of cocaine addiction]. Rev Prat. 2009;59(6):825-9.

29. O'Brien MS, Wu LT, Anthony JC. Cocaine use and the occurrence of panic attacks in the community: a case-crossover approach. Subst Use Misuse. 2005;40:285-97.

30. Sareen J, Chartier M, Paulus MP, Stein MB. Illicit drug use and anxiety disorders: findings from two community surveys. Psychiatry Res. 2006;142:11-7. Epub 2006 May 19.

31. Marmorstein NR. Anxiety disorders and substance use disorders: different associations by anxiety disorder. J Anxiety Disord. 2012;26:88-94. Epub 2011 Oct 1.

32. Glantz MD, Anthony JC, Berglund PA, Degenhardt L, Dierker L, Kalaydjian $A$, et al. Mental disorders as risk factors for later substance dependence: estimates of optimal prevention and treatment benefits. Psychol Med. 2009;39:1365-77. Epub 2008 Dec 2.

33. Falk DE, Yi HY, Hilton ME. Age of onset and temporal sequencing of lifetime DSM-IV alcohol use disorders relative to comorbid mood and anxiety disorders. Drug Alcohol Depend. 2008;94:23445. Epub 2008 Jan 22.

\section{Correspondence:}

Andressa Jacondino Pires

Rua Conselheiro Brusque, 49

96600-000 - Canguçu, RS - Brazil

Tel.: +55 (53) 3252.1664

E-mail: andressajpires@yahoo.com.br 